\title{
PENGEMBANGAN BUKU PENGAYAAN MEMBACA SASTRA LEGENDA BERMUATAN MULTIKULTURAL
}

\author{
Hany Uswatun Nisa \\ Program Studi Pendidikan Bahasa dan Sastra Indonesia, Fakultas Keguruan dan Ilmu \\ Pendidikan, Universitas Muhadi Setiabudi Brebes, Indonesia \\ e-mail: hanyuswatunnisa@gmail.com
}

\begin{abstract}
Abstrak
Buku pengayaan merupakan komponen yang sangat penting yang digunakan guru dalam pembelajaran. Buku pengayaan yang baik dapat membantu peserta didik dalam kecendrungan dititikberatkan hanya ada satu buku pengayaan. Padahal banyak pilihan sumber buku yang dapat digunakan. Pembelajaran membaca sastra legenda merupakan salah satu kompetensi dasar dalam kurikulum sekolah menegah pertama (SMP) kelas VIII. Maka dari itu perlu pengembangan buku pengayaan membaca sastra legenda. Penelitian ini bertujuan untuk: mengetahui keefektifan penggunaan buku pengayaan membaca sastra legenda berkonteks multikultural untuk peserta didik kelas VIII SMP. Penelitian ini menggunakan pendekatan R\&D (Reseach and Development). Hasil uji keefektifan membaca sastra legenda berkonteks multicultural menyatakan buku ini efektif digunakan dengan berdasarkan hasil uji t di SMP N 1 ketanggungan, nilai signifikasi 0,000 $<0,05$. Artinya kedua perlakuan tersebut memiliki perbedaan yang signifikan. Dengan kata lain hasil postes lebih baik daripada pretes yaitu 88,79 dibandingkan nilai rata-rata pretest yaitu 69,88 .
\end{abstract}

Kata kunci: buku pengayaan, membaca sastra legenda, dan multicultural.

\begin{abstract}
Enrichmen books are a very important component used by teachers in learning. A good enrichment book can help students in a tendency to emphasize only on enrichment books. Even though there areamny choices of book sources that can be used. Learning to read legendary literature is one of the basic competencies in the 8th grade junior high school curriculum. Therefore, it is necessary to develop a book that reads legendary literature. This study aims to determine the effectiviness of the use of multicultural contextual literary reading enrichment books for grade 8 junior high school students. This research uses research and developmrnt approach. The results pf theeffectivenessreading test of the multicultural contextual literary legend state that this book is effectively used based on the results of theT test in junior high 1, the significance value is $0,000<0,05$. Meaning that the two treatments have significant differences. In other words the results of the posttest are better than pretest. That is 88,79 compared to the value of pretest wich is 69,88.
\end{abstract}

Keywords: enrichment books, reading literary legends, multicultural.

\section{PENDAHULUAN}

Buku pengayaan merupakan komponen penting yang digunakan guru dalam kegiatan pembelajaran. Bahan ajar yang baik dapat membantu peserta didik dalam rangka mencapai kompetensi. Sumber bahan ajar yang dipilih guru ada kecendrungan dititikberatkan hanya ada satu bahan ajar. Padahal banyak pilihan sumber bahan ajar yang digunakan. Proses kegiatan belajar mengajar guru juga cenderung memberikan bahan ajar terlalu luas atau sebaliknya terlalu sedikit, terlalu mendalam atau justru terlalu dangkal, urutan penyajian yang

Submitted: 2019, Accepted: 2019, Published: Agstus 2019

ISSN: xxxx-Xxxx (online), Website: http://jurnal.umus.ac.id/index.php/semantika 
tidak tepat, dan jenis materi bahan ajar yang tidak sesuai dengan kompetensi peserta didik yang ingin dicapai sesuai tuntutan Kurikulum 2013.

Merujuk pada Pedoman Memilih Menyusun Bahan Ajar (Depdiknas, 2006:1), pemilihan bahan ajar meliputi cara penentuan jenis materi, kedalaman, ruang lingkup, urutan penyajian, perlakuan terhadap bahan ajar. Jenis materi yang dipilih hendaknya sesuai dengan tujuan kompetensi yang akan dicapai peserta didik. Kedalaman materi juga disesuaikan dengan kondisi kemampuan peserta didik, sehingga peserta didik benar-benar nyaman ketika belajar dengan materi tersebut. Ruang lingkup dan urutan penyajian harus dapat menjawab permasalahan yang dibahas sesuai dengan kompetensi. Perlakuan terhadap bahan ajar dapat mengubah dan membantu peserta didik dari yang awalnya mengalami kesulitan memahami materi menjadi mudah dalam memahaminya.

Berdasarkan paparan tersebut, buku pengayaan merupakan sarana dan sumber belajar yang penting dan dapat membantu peserta didik dalam mengembangkan pengetahuan, keterampilan, dan kepribadian, baik di sekolah maupun di luar sekolah. Oleh karena itu, dalam pembelajaran diperlukan bahan ajar yang benar-benar tepat dan sesuai dengan kebutuhan peserta didik, guru, dan pembaca, atau masyarakat lainnya yang peduli terhadap pendidikan, sesuai dengan kurikulum, perkembangan lingkungan, dan iptek masa akan datang.

Pembelajaran membaca sastra legenda merupakan salah satu kompetensi dasar dalam kurikulum mata pelajaran bahasa Jawa pada Sekolah Menengah Pertama (SMP) kelas VIII. Di dalam pembelajaran membaca sastra legenda, diharapkan peserta didik dapat menyimpulkan isi cerita legenda. Selain itu, melalui kegiatan membaca peserta didik diharapkan mampu mendalami, menghayati, dan mengambil manfaat ataupun pesan dari isi cerita tersebut. Hal ini senada dengan pendapat peneliti [1] bahwa membaca merupakan proses yang dilakukan dan digunakan oleh pembaca untuk memperoleh pesan yang disampaikan oleh penulis melalui katakata tulis.

Nyatanya, belum banyak buku mengenai membaca sastra legenda. Maka dari itu, perlu pengembangan buku pengayaan membaca sastra legenda untuk menunjang pembelajaran. Berdasarkan pengamatan di sekolahsekolah, buku yang tersedia untuk Kurikulum 2013 hanyalah buku yang dibuat oleh pemerintah. Buku tersebut yakni buku pegangan peserta didik dan buku pegangan guru. Namun, setelah diamati porsi materi yang disajikan, khususnya untuk keterampilan membaca sastra legenda masih kurang. Penyajian materi masih secara umum, belum mendalam.

Dalam penelitian ini nilai-nilai multikultural dimuatkan dalam buku pengayaan membaca sastra legenda. Nilai-nilai positif yang terkandung dalam multicultural diharapkan dapat membentuk karakter peserta didik. Di samping itu, kearifan lokal juga memiliki beragam kelebihan, diantaranya menumbuhkan kesadaran peserta didik dalam menjaga, mencintai, dan melestarikan budayanya sendiri. Sebagaimana yang ditulis oleh peneliti [2] bahwa kearifan lokal dapat diinternalisasikan dalam pendidikan karena memiliki kelebihan. Kelebihan tersebut sebagai berikut: (1) multikultural dapat menjadi sarana pembelajaran bagi setiap manusia untuk menjadi orang yang cerdas, pandai, dan bijaksana, (2) multikultural memiliki nilai-nilai positif untuk dapat ditransformasikan kepada peserta didik 
guna membentuk kepribadian positif. Dengan demikian, kiranya tepat jika multikultural menjadi muatan dalam buku pengayaan membaca sastra legenda.

Dari paparan tersebut telah dikemukan beberapa alasan dikembangkannya buku pengayaan membaca sastra legenda berkonteks multikultural. Pengembangan buku pengayaan ini dapat memudahkan peserta didik dalam memahami materi. Selain itu, juga dapat meningkatkan keterampilan peserta didik dalam membaca sastra legenda.

\section{KAJIAN TEORI}

Hasil penelitian [3] menunjukkan hubungan antara kemampuan membaca terhadap kemampuan mengapresiasi prosa terdapat pengaruh positif dan signifikan. Hal ini terbukti dengan nilai $t$ hitung $(5,496)$ dengan tingkat signifikansi sebesar $0,000>t$ table (2000), yang berarti ada tingkat signifikansi sebesar 0,05 .

Penelitian yang berkaitan dengan pembelajaran berbasis budaya pernah dilakukan oleh peneliti [4] dimana tujuannya yaitu mengintegrasikan budaya dalam pembelajaran untuk mengenalkan sikap mencintai budaya daerah pada peserta didik. Adapun metode penelitian yang digunakan adalah deskriptif kualitatif. Hasil penelitian menunjukkan bahwa pembelajaran berbasis multikultural sangat penting dan perlu diterapkan dalam proses pembelajaran, karena nilainilai budaya yang terkandung dapat memperkenalkan segala potensi yang ada di suatu daerah kepada peserta didik yang dapat menumbuhkan rasa bangga dan cinta terhadap tanah air. Relevansi penelitian ini dengan penelitian [4] adalah pada muatan yang diintegrasikan yaitu kebudayaan. Adapun perbedaan kedua penelitian ini terletak pada metode penelitian yang digunakan. Pada penelitian [4] digunakan metode penelitian deskriptif kualitatif, sedangkan penelitian ini digunakan metode research and development.

Menurut [5] yang dimaksud buku adalah kumpulan kertas berisi informasi, tercetak, disusun secara sistematis, dijilid serta bagian luarnya dibeli pelindung serta diberi kertas tebal, karton, atau bahan lain.

Buku yang memuat materi dapat memperkaya dan meningkatkan penguasaan IPTEK dan keterampilan.

Karakteristik Buku Nonteks Pelajaran atau Buku Pengayaan

Pada pedoman penulisan buku nonteks yang diterbitkan oleh pusat perbukuan disebutkan bahwa dalam menulis buku nonteks pelajaran diperlukan pemahaman tentang ketentuan dasar dan komponenkomponen yang menjadi karakteristik penerbitan buku nonteks pelajaran.

Pengertian Membaca

Ada beberapa macam pendapat tentang pengertian membaca. Para ahli umumnya berpendapat bahwa pada dasarnya membaca merupakan proses yang kompleks. Berdasarkan kekomplekan dalam membaca, penegrtian membaca dapat diklasifikasikan menjadi tiga, yaitu pengertian membaca yang kompleks dan sangat kompleks. Pengertian membaca yang kompleks [6], [7], [8]. Menurut mereka membaca merupakan aktivitas yang kompleks karena tidak hanya mengamati tulisan secara visual saja, tetapi juga menggunakan pikiran untuk memahami bacaan. Pemahaman seseorang dalam membaca bergantung pada kecakapan dalam menjalankan setiap organ tubuh yang diperlukan dalam aktivitas membaca. 
Jurnal SEMANTIKA, Volume 1, No. 01, Agustus 2019, p. 63-75

\begin{abstract}
Selanjutnya, pengertian membaca yang sangat kompleks diungkapkan oleh [9], [10], [11]. Menurut mereka membaca merupakan aktivitas berbahasa yang sangat kompleks karena berperan dalam menyerap ilmu dari bahan yang telah dibaca. Aktivitas ini memerlukan kemahiran yang khusus terutama dalam memastikan kepahaman pelajar berkenaan bahan yang dibaca memberikan manfaat dan berkesan. Pembaca yang baik akan selalu dapat menangkap pengalaman-pengalaman yang sangat berharga, walaupun hal itu belum atau tidak pernah dialami oleh pembaca secara langsung.
\end{abstract}

Atas dasar pengertian itu dapat disimpulkan bahwa membaca adalah seluruh aktivitas yang dilakukan pembaca untuk memperoleh informasi yang terkandung dalam sebuah bacaan. Adapun aktivitas yang dilakukan pembaca tidak sekedar aktivitas visual, tetapi juga adanya proses berpokir dalam menafsirkan makna yang terkandung dalam bacaan.

Pengertian Membaca Sastra Legenda

Menurut Tim Penyusun Kamus Pusat Bahasa, membaca sastra legenda yaitu membaca cerita rakyat zaman dahulu yang ada hubungannya dengan sejarah pada masa lampau. Sedangkan legenda yaitu kejadian pada masa lampau. Legenda juga dipandang sebagai sejarah. Legenda mempunya ciri-ciri yaitu kejadian yang benar-benar nyata yang terjadi di daerah itu sendiri pada masa lampau.

Selanjutnya pengertian
membaca sastralegenda Jawajuga
merupakan membaca yang bercermin
pada karya sastra Jawa dari keserasian,
keharmonisan antara bentuk dan
keindahan isi. Oleh karena itu, membaca
sastra Jawa dapat diartikan sebagai
proses membaca dan memahami suatu
bacaan sastra Jawa dengan melihat unsur

intrinsik dan ekstrinsiknya seperti dalam puisi, cerpen, novel, drama dan sebagainya.

\section{Tujuan Membaca sastra Legenda}

Berdasarkan uraian sebelumnya tentang membaca dan membaca sastra legenda maka dapat dikatakan bahwa membaca sastra legenda merupakan aktivitas yang dilakukan pembaca untuk memperoleh informasi yang terkandung dalam sebuah cerita legenda pada zaman dahuku yang ada hubungannya dengan sejarah pada masa lampau.

Kegiatan membaca termasuk membaca sastra legenda erat kaitannya dengan tujuan membaca, karena seseorang yang membaca dengan suatu tujuan, cenderung lebih memahami dibandingkan dengan orang yang tidak mempunyai tujuan.

Ada berbagai keragaman tujuan membaca. Menurut [1], [9 tujuan membaca dibedakan menjadi dua, yakni tujuan utama dan tujuan khusus. Tujuan utama dalam membaca adalah mencari serta memperoleh informasi, mencakup isi, dan memahami makna bacaan. Tujuan khusus dalam membaca adalah memperoleh informasi factual, memperoleh keterangan tentang sesuatu yang khusus dan problematic, memberikan penilaian kritis terhadap karya tulis seseorang, memperoleh kenikmatan emosi, dan mengisi waktu luang.

Lebih lanjut penulis [12] mengungkapkan bahwa tujuan membaca mencakupi 1) kesenangan, 2) menyempurnakan membaca nyaring, 3) menggunakan strategi tertentu, 4) memperbaharui pengetahuannya tentang suatu topic, 5) mengaitkan informasi baru dengan informasi yang telah diketahuinya, 6) memperoleh informasi untuk laporan lisan atau tertulis, 7) mengkonfirmasikan atau menolak prediksi, dan 8) menampilkan suatu 
eksperimen atau mengaplikasikan informasi yang diperoleh.

Dari penjelasan itu dapat dinyatakan bahwa tujuan membaca dapat dibagi menjadi dua yaitu tujuan umum dan tujuan khusus. Dikatakan tujuan membaca umum, manakala aktivitas membaca tersebut untuk memperoleh kesenangan semata, sedangkan tujuan membaca khusus untuk memperoleh informasi sebagai tugas yang berkaitan dengan akademik. Dalam penelitian ini tujuan membaca teks sastra legenda tergolong dalam tujuan membaca khusus karena untuk memperoleh informasi mengenai karya sastra legenda.

\section{Struktur Teks Sastra Legenda}

Dongeng atau cerita legenda menurut ensiklopedi Wikipedia bahasa Indonesia merupakan bentuk cerita tradisional atau cerita yang disampaikan secara teruntemurun dari nenek moyang yang memiliki fungsi untuk mengajarkan nilai-nilai moral dan juga sebagai hiburan.

Dari pengertian di atas, bisa mengambil point penting bahwa dongeng atau cerita legenda itu merupakan salah satu karya sastra yang menceritakan suatu hal fiktif untuk diambil pelajaran dan sebagai hiburan bagi masyarakat.

Sebuah karya sastra legenda dibangun oleh tiga bagian penting, yaitu pendahuluan, isi atau peristiwa, dan penutup. Berikut penjelasan dari masingmasing bagian dari sastra legenda.

1. Pendahuluan, berisi kalimat pengantar untuk memulai legenda.

2. Isi (Peristiwa), bagian penting dari legenda yang isinya mengenai urutan kejadian dari suatu peristiwa.

3. Penutup, bagian akhir cerita yang dibuat untuk mengakhiri cerita.
Pendidikan Multikultural

Kemajemukan merupakan salah satu fakta sosial yang ada di Indonesia dan sebagian negara-negara di dunia. Sejalan dengan itu muncullah berbagai konsep yang berkaitan dengan pendidikan untuk masyarakat majemuk. Salah satunya adalah pendidikan multikultural. Konsep ini menurut [13] Hakikatnya pendidikan multikultural menekankan kepada pembentukan lingkungan pendidikan. Siswa dari berbagai kelompok budaya akan mendapatkan pengalaman pendidikan yang adil. Iklim kesamaan yang diciptakan sekolah akan berkesempatan terjadinya interaksi positif antarsiswa, siswa dengan guru, maupun siswa dengan personal lainnya. Sementara menurut Sosiolog UI Parsudi Suparlan sebagaimana dikuti pada penelitian [12] pendidikan multikultural adalah konsep yang mampu menjawab tantangan perubahan zaman dengan alasan multikulturalisme merupakan sebuah idiologi yang mengagungkan perbedaaan budaya atau sebuah keyakinan yang mengakui dan mendorong terwujudnya pluralisme budaya sebagai corak kehidupan masyarakat. Sesuai dengan konsep pendidikan multikultural, pada intinya pembelajaran diupayakan untuk menciptakan kondisi yang demokratis bagi siswa.

Menurut [14] pendidikan multikultural berarti adanya keragaman etnik dan budaya masyarakat suatu bangsa. Pendidikan mulikultural mengakui tiap budaya memiliki nilai sendiri sehingga tidak ada satu-satunya nilai paling benar. Untuk itu, diperlukan keterbukaan hati dan pikiran akan relativitas nilai budaya. Pendidikan multikultural merupakan salah satu alternatif untuk tidak sekadar merekatkan kembali nilai-nilai persatuan 
dan kesatuan, tetapi juga mendefinisikan kembali rasa kebangsaan itu sendiri.

Ide pendidikan multikultural telah menjadi komitmen global sebagaimana direkomendasi UNESCO pada bulan Oktober 1994 di Jenewa. Rekomendasi itu memuat empat pesan, yaitu (1) pendidikan hendaknya mengembangkan kemampuan untuk mengakui dan menerima nilai-nilai yang ada dalam kebhinekaan, (2) pendidikan hendaknya meneguhkan jati diri dan memperkokoh perdamaian, persaudaraan, dan solidaritas, (3) pendidikan hendaknya meningkatkan kemampuan menyelesaikan konflik secara damai, dan (4) pendidikan hendaknya meningkatkan pengembangan peserta didik dalam membangun kualitas toleransi, kesabaran, dan kemauan untuk berbagi dan [12].

Pesan pendidikan multikultural hendaknya dijadikan dorongan bagi lembaga pendidikan agar menanamkan sikap menghargai orang, budaya, agama, dan keyakinan lain. Implementasi pendidikan berwawasan multikultural bermanfaat bagi siswa untuk mengerti, menerima, dan menghargai diri sendiri dan orang lain. Melalui penanaman semangat multikulturalisme, sekolah merupakan media pelatihan dan penyadaran siswa untuk menerima perbedaan budaya, agama, ras, etnis, dan kebutuhan di antara sesama sehingga mau hidup bersama secara damai. Paradigma multikultural ini secara implisit tertuang dalam Pasal 4 ayat 1 UU Nomor 20 Tahun 2003 tentang Sistem Pendidikan Nasional “ pendidikan diselenggarakan secara demokratis, tidak diskriminatif dengan menjunjung tinggi hak asasi manusia, nilai keagamaan, nilai kultural, dan kemajemukan bangsa."

Pendidikan multikultural di sekolah merupakan respons terhadap perkembangan keragaman populasi sekolah. Pendidikan menuntut persamaan hak bagi setiap siswa tanpa membedakan agama, gender, etnik, ras, budaya, ataupun strata sosial. Sebagai wacana baru, pendidikan multikultural tidak harus dirancang khusus sebagai muatan substansi tersendiri, tetapi dapat diintegrasikan melalui bahan ajar atau model pembelajaran yang memungkinkan diterapkannya pendidikan multikultural. Pendidikan multikultural ini dapat diintegrasikan melalui mata pelajaran seperti $P P K n$, agama, IPS, dan bahasa Indonesia, atau dapat melalui model lain seperti kelompok diskusi atau kegiatan ekstrakurikuler.

Banks dalam [15] menjelaskan empat dimensi pelaksanaan pendidikan multikultural, yaitu (1) content integration, (2) the knowledge construction process, (3) an equity paedagogy, dan (4) perjudice reductio. Content integration yaitu mengintegrasikan berbagai budaya dan kelompok untuk mengilustrasikan konsep mendasar, generalisasi, dan teori dalam mata pelajaran bahasa Indonesia. The knowledge construction proces yaitu membawa siswa untuk memahami implikasi budaya ke dalam mata pelajaran bahasa Indonesia. An equity paedagogy yaitu menyesuaikan metode pengajaran dengan cara belajar siswa dalam rangka memfasilitasi prestasi akademik siswa yang beragam baik dari segi ras, budaya ataupun sosial. Perjudice reductio yaitu mengidentifikasi karakteristik ras siswa dan menentukan metode pengajaran mereka.

Menurut [13] ada tiga tipologi pengimplementasian pendidikan multikultural, yaitu (1) program berorientasi isi, (2) program berorientasi siswa, dan (3) program berorientasi masyarakat. Program berorientasi isi berarti memasukkan 
isi tentang kelompok budaya yang berbeda-beda kedalam kurikulum dan bahan ajar sehingga pengetahuan siswa tentang kelompok-kelompok tersebut meningkat. Program berorientasi siswa yaitu program yang tidak mengubah kurikulum, tetapi didesain untuk menolong perbedaan latar belakang siswa. Program berorientasi masyarakat yaitu program yang didesain tidak hanya untuk merestrukturisasi dan menghilangan perbedaan sekolah, tetapi juga untuk meningkatkan berbagai kontak antarras

Penulis [15] menegaskan bahwa pendidikan multikultural tidak diarahkan semata-semata kepada ranah rasial, agama dan budaya, tetapi lebih difokuskan untuk menumbuhkan sikap toleran dan mengakui pluralisme dalam masyarakat. Sekaligus sebagai upaya mengurangi ketegangan yang diakibatkan oleh perbedaan di dalam masyarakat. Untuk itu diperlukan upaya mereduksi berbagai jenis prasangka negatif yang potensial hidup di dalam masyarakat. Sejalan dengan itu, penulis [16] menegaskan bahwa dalam masyarakat multikultur perlu dibangun paradigma pemahaman keberagaman, yaitu (1) menghargai keragaman bahasa, (2) membangun sikap sensitif gender, (3) membangun pemahaman terhadap perbedaan status sosial, (4) membangun sikap antidiskriminasi etnis, (5) menghargai perbedaan kemampuan, dan (6) menghargai perbedaan umur.

Dalam upaya menumbuhkan sikap toleransi dibutuhkan pengetahuan, pengalaman, aktivitas mengeksplorasi nilai-nilai multikultural sebagai perwujudan nilai-nilai pribadi dan sosial. Untuk itu memprogramkan pendidikan nilai, yang meliputi (1) ketaatan, (2) penghargaan, (3) toleransi, (4) tanggung jawab, (5) kebersamaan/kerja sama, keadilan, (7) kejujuran, (8) rendah hati, (9) cinta dan kasih sayang, (10) kesederhanaan, (11) kebebasan, dan (12) persatuan. Nilai-nilai tersebut bersifat universal. Namun, dibalik keuniversalan itu terdapat keberagaman dalam bahasa, budaya, atau etnik yang berbeda. Nilai-nilai itu dikemukakan untuk ditemukan kesamaan dan perbedaannya sebagai landasan menuju persatuan dalam keberagaman.

Tujuan akhir pendidikan multikultural menurut [16] tidak hanya menguasai materi pelajaran, tetapi siswa akan memiliki karakter yang kuat untuk bersikap demokratis, pluralis, dan humanis. Pendidikan multikultural diharapkan dapat membangun karakter siswa SMP dalam relasinya dengan diri sendiri dan sesama. Hal ini ditegaskan oleh Banks sebagaimana dikutip [13] bahwa pendidikan multikultural seharusnya mengembangkan tiga hal, yaitu (1) menolong siswa mengembangkan identitas diri, (2) menolong siswa mengembangkan konsep diri, dan (3) menolong siswa mengembangkan pemahaman diri.

Peran guru $\begin{array}{r}\text { dalam } \\ \text { berkonteks } \\ \text { pembelajaran }\end{array}$
multikultural adalah $\begin{array}{r}\text { sebagai } \\ \text { fasilitator. Apa yang disampaikan }\end{array}$
guru, cara guru mengajar, dan
kepribadian guru sangat
mempengaruhi keberhasilan
pembelajaran. Demikian juga latar
belakang kultur guru akan turut
membentuk persepsi murid terhadap
kulturnya. Penulis [17] menyatakan
bahwa guru yang tidak memahami
latar belakang budayanya sendiri,


Jurnal SEMANTIKA, Volume 1, No. 01, Agustus 2019, p. 63-75

tidak sensitif budaya, atau tidak memiliki pemahaman multikultur tidak bisa diharapkan sukses dalam menerapkan pendidikan multikultur. Oleh karena itu, sangatlah penting bagi guru untuk memiliki wawasan dan pemahaman multikultur agar mampu melaksanakan pembelajaran berkonteks multikultur dengan efektif.

\section{METODE PENELITIAN}

Pendekatan penelitian yang digunakan dalam penelitian ini adalah penelitian dan pengembangan (research and development). Menurut [18] penelitian dan pengembangan digunakan untuk menghasilkan produk tertentu. Adapun produk pendidikan tidak hanya mencakup wujud material, seperti bukubuku teks, film-film pembelajaran dan sebagainya, "educational research and development is a process used to develop and validate educational product", tetapi juga yang berhubungan dengan pengembangan proses dan prosedur, seperti pengembangan metode mengajar, pengembangan instrumen/perangkat pembelajaran, atau metode pembelajaran, dan sejenisnya. Berdasarkan pendapat itu, pendekatan penelitian dan pengembangan dipandang memiliki relevansi untuk digunakan dalam pengembangan model pembelajaran menulis petunjuk berkonteks multikultural dalam pembentukan karakter siswa.

Penelitian ini merupakan penelitian kualitatif deskripstif. Hal ini dapat dilihat dari data yang digunakan dalam penelitian. Data dalam penelitian ini berupa hasil belajar memahami isi cerita kelas VIII SMP.

Variabel Penelitian

Dalam penelitian ini terdapat dua variabel yaitu variable bebas dan variable terikat. Variabel bebas dalam penelitian ini yaitu pengembangan buku pengayaan membaca sastra legenda bermuatan multikultural berbahasa Jawa untuk peserta didik kelas VIII SMP/MTS. Variable terikatnya yaitu kemampuan membaca sastra legenda dan pemahaman muatan multikultural bagi peserta didik kelas VIII SMP/MTS. Data dan Sumber Data

Data dan sumber data dalam penelitian ini meliputi data penelitian, sumber data penelitian.

\section{Data Penelitian}

Data yang diperlukan dalam pengembangan buku pengayaan membaca sastra legenda bermuatan multikultural untuk peserta didik kela VIII SMP/MTS, yaitu a) data kebutuhan pengembangan buku pengayaan menurut persepsi guru dan peserta didik, b) data prinsip-prinsip pengembangan buku pengayaan dan uji validasi terhadap draf buku pengayaan berwujud skor penilaian produk buku pengayaan oleh validator bahan ajar yaitu guru dan ahli, dan c) data skor akhir data uji keefektifan draf buku pengayaan oleh peserta didik kelas VIII SMP/MTS.

Wujud data kebutuhan pengembangan buku pengayaan menurut persepsi guru dan peserta didik ialah skor kecenderungan kebutuhan peserta didik dan guru terhadap bahan ajar yang akan dikembangkan. Data pkarakteristik pengembangan buku pengayaan berupa pertanyaan-pertanyaan dari beberapa ahli mengenai prinsip pengembangan buku pengayaan. Data uji validasi ahli terhadap draf buku pengayaan berwujud skor penilaian produk buku pengayaan oleh validator yaitu guru dan ahli. Data uji keefektifan draf buku pengayaan berwujud skor pemahaman peserta didik mengenai membaca sastra legenda.

Sumber Data Penelitian

Sumber data dalam penelitian ini berupa sumber data untuk analisis 
Jurnal SEMANTIKA, Volume 1, No. 01, Agustus 2019, p. 63-75

kebutuhan, sumber data uji validasi, dan sumber data uji keefektifan.

\section{Sumber Data Analisis Kebutuhan}

Sumber data analisis kebutuhan diambil dari tiga sekolah yang berbeda. Adapun sekolah-sekolah tersebut dipilih berdasarkan karakteristik sekolah yang berbeda. Adapun ketiga sekolah tersebut yaitu SMP N 1 Ketanggungan, SMP N 3 Pangkah, dan MTS Comal.

\section{Peserta Didik}

Peserta didik yang menjadi sumber data yaitu peserta didik SMP dari tiga sekolah yang berbeda. Hal tersebut dibedakan dari sekolah unggulan maupun tidak unggulan dengan tujuan agar produk bahan ajar membaca sastra legenda bisa dipakai untuk semua karakteristik SMP/MTS. Jadi produk buku pengayaan yang dihasilkan tidak hanya dipakai untuk karakteristik sekolah unggulan saja tetapi juga bisa dipakai untuk sekolah dengan karakteristik tidak unggulan.

2. Guru

Guru bahasa Jawa yang menjadi sumber data dalam penelitian ini adalah guru bahasa Jawa dari tiga sekolah yaitu SMP N 1 Ketanggungan, SMP N 3 Pangkah, dan MTS Comal. Pemilihan beberapa guru tersebut diharapkan agar data yang terjaring lebih dapat mewakili beragam kebutuhan dan permasalahan dalam pembelajaran.

Sumber Data Uji Validasi Produk

Sumber data validasi produk dilakukan pada guru dan dosen ahli.

1. Guru

Validasi produk membutuhkan saran dan penilaian dari guru yang menjadi subjek analisis kebutuhan pada tahapan sebelumnya. Dalam penelitian ini, guru yang memvalidasi produk buku pengayaan membaca sastra legenda bermuatan multikultural yang berkompeten dalam mata pelajaran bahasa Jawa. Sumber data validasi produk yaitu Drs. Teguh Wiyono berasal dari guru SMP N 1 Ketanggungan.

2. Dosen Ahli

Dosen ahli yang bertindak sebagai penguji dan pemberi saran perbaikan draf buku pengayaan membaca sastra legenda bermuatan multikultural yaitu Prof. Dr. Agus Nuryatin, M. hum, dan Dr. Haryadi, M.Pd.

\section{Sumber Data Uji Keefektifan}

Sumber data uji keefektifan terdiri atas peserta didik. Uji coba terbatas dilakukan untuk menguji keefektifan buku pengayaan membaca sastra legenda bermuatan multikultural untuk peserta didik kelas VIII SMP/MTS. Peserta didik yang menjadi objek uji coba produk bahan ajar adalah peserta didik kelas VIII di SMP N 1 Ketanggunagn Brebes, dan peserta didik kelas VIII di SMP N 2 Banjarharjo Brebes. Alasan pemilihan kota Brebes karena sesuai dengan judul bahan ajar "Ayo Maca Wacan sastra Legendha Muatan mulikulturall dhaerah Pantura Kulon", jadi sebagai daerah yang terletak paling barat di Jawa Tengah, kota Brebes mewakili dhaerah pantura lainnya sebagian wilayah bagian barat.

Instrumen Penelitian

Dibutuhkan tiga macam instrumen dalam pengembangan buku pengayaan membaca sastra legenda bermuatan multikultural berbahasa Jawa untuk peserta didik kelas VIII SMP/MTS, yaitu (1) instrumen kebutuhan buku pengayaan membaca sastra legenda bermuatan multicultural berbahasa Jawa untuk peserta didik kelas VIII SMP/MTS, (2) instrumen validasi buku pengayaan membaca sastra legenda bermuatan multicultural berbahasa Jawa untuk peserta didik kelas VIII SMP/MTS, (3) instrumen uji kelas terbatas buku pengayaan membaca sastra legenda bermuatan multikultural 
Jurnal SEMANTIKA, Volume 1, No. 01, Agustus 2019, p. 63-75

berbahasa Jawa untuk peserta didik kelas VIII SMP/MTS

\section{HASIL DAN PEMBAHASAN}

Penelitian ini bertujuan untuk mengetahui apakah ada perbedaan keterampilan membaca sastra legenda yang signifikan antara siswa yang mendapat pembelajaran menggunakan buku pengayaan membaca sastra legenda bemuatan multikultural dan siswa yang mendapat pembelajaran dengan strategi konvensional. Penelitian ini juga bertujuan untuk menguji keefektifan buku pengayaan membaca sastra legenda bemuatan multicultural pada peserta didik kelas VIII SMP. Data dalam penelitian ini diperoleh dari skor pretest untuk mengetahui kemampuan awal siswa membaca pemahaman teks argumentasi dan skor posttest untuk mengetahui kemampuan akhir siswa membaca pemahaman teks argumentasi. Hasil penelitian siswa kelompok eksperimen dan kelompok kontrol disajikan sebagai berikut:

1. Deskripsi Data Penelitian

Hasil penelitian yang dilaksanakan dengan desain Pretest Posttest Control Group Design ini menghasilkan skor keterampilan membaca sastra legenda dari kelompok kontrol dan kelompok eksperimen. Masing-masing berupa tes awal membaca pemahaman teks membaca sastra legenda (pretest) dan tes akhir membaca sastra legenda (posttest).

a. Deskripsi Data Skor Pretest- Posttest Kemampuan Membaca

Pemahaman Kelompok Kontrol dan Kelompok Eksperimen. Data yang diperoleh dari pretest dan posttest kedua kelompok diolah dengan program SPSS 16. Hasil pengolahan data selengkapnya dapat dilihat pada $\mu 2=$ Tidak adanya strategi Mastery
Learning dalam pembelajaran membaca pemahaman teks argumentasi.

2. Hipotesis Kedua

Ho $=\mu 1=\mu 2$

$\mathrm{Ha}=\mu 1>\mu 2$

Ho $=$ buku pengayaan tidak lebih efektif digunakan dalam pembelajaran

membaca sastra legenda kelas VIII SMP Negeri

$\mathrm{Ha}=$ buku pengayaan lebih efektif digunakan dalam pembelajaran

$\mu 1=$ Penggunaan buku pengayaan membaca sastra legenda

$\mu 2=$ Tidak adanya buku pengayaan dalam pembelajaran

I. Hipotesis Statistik

Hipotesis statistik atau hipotesis nol (Ho) menyatakan tidak ada pengaruh variabel bebas dengan variabel terikat. Artinya, selisih variabel pertama dan kedua adalah sebagai berikut:

1. Hipotesis Pertama

Ho $=\mu 1=\mu 2$

$\mathrm{Ha}=\mu 1 \neq \mu 2$

Ho = Tidak terdapat perbedaan keterampilan membaca sastra legenda yang signifikan antara siswa yang mendapat pembelajaran membaca sastra legenda menggunakan buku pengayaan bermuatan multikultural dengan siswa yang mendapat pembelajaran membaca sastra legenda dengan menggunakan strategi konvensional pada siswa kelas VIII SMP Negeri 1Ketanggungan.

$\mathrm{Ha}=$ Terdapat perbedaan keterampilan membaca sastra legenda yang signifikan antara siswa yang mendapat pembelajaran membaca sastra legenda menggunakan buku pengayaan dengan siswa yang mendapat pembelajaran membaca sastra legenda dengan menggunakan strategi konvensional pada siswa kelas VIII SMP Negeri 1 Ketanggungan.

$\mu 1=$ Penggunaan buku pengayaan membaca sastra legenda bermuatan multicultural. 
2. Uji Persyaratan Analisis

Ada dua hal yang harus dipenuhi bila menggunakan analisis uji-t, yaitu uji normalitas sebaran dan uji homogenitas varian.

a. Uji Normalitas Sebaran

Uji normalitas sebaran berfungsi untuk mengetahui normal atau tidaknya sebaran data penelitian. Pada penelitian ini, uji normalitas dilakukan terhadap skor pretest dan posttest kelas eksperimen dan kelas kontrol. Uji normalitas dalam penelitian ini menggunakan tes statistik Kolmogorov Smirnov yang berindeks 0,090 (Nurgiyantoro, 2012:118). Kriteria penilaiannya, yaitu jika signifikasi lebih besar dari $0,05 \quad(\mathrm{p}>0,05)$ dapat disimpulkan bahwa data tersebut berdistribusi normal. Apabila signifikasi lebih kecil dari $0,05(\mathrm{p}<0,05)$ dapat disimpulkan data berasal dari populasi yang memiliki sebaran tidak normal.

Pengujian normalitas data dilakukan dengan menggunakan bantuan program

b. Uji Homogenitas Varian

Uji homogenitas dimaksudkan untuk mengetahui kesamaan beberapa sampel, yaitu seragam tidaknya sampelsampel yang diambil dari populasi yang sama. Syarat data dikatakan bersifat homogen jika taraf signifikasi kedua

kelompok lebih besar dari 0,05 ( $p>0,05)$. Uji homogenitas dalam penelitian ini 38

yang digunakan dalam penelitian ini dengan rumus ITEMAN yang ditunjukkan

oleh nilai alpha cronbach.

Tabel 4: Nilai Alpha Cronbach

0,00 - 0,20 Sangat Rendah

0,20 - 0,40 Rendah

0,40 - 0,70 Sedang

0,70 - 0,90 Tinggi

0,90 - 1,00 Sangat Tinggi

Uji reliabilitas instrumen

menggunakan prosedur konsistensi internal dengan teknik alpha cronbach dengan bantuan SPSS versi 16. Pengujian ini dilakukan pada siswa di luar sampel penelitian, yaitu kelas VIII A yang berjumlah 30 siswa. Kelas tersebut merupakan kelas di luar kelompok kontrol dan kelompok eksperimen. Berdasarkan hasil uji reliabilitas, diperoleh nilai alpha sebesar 0,839

sehingga dinyatakan reliabel karena lebih besar dari 0,6 .

\section{SIMPULAN}

Berdasarkan hasil tindakan yang berdasarkan hasil penelitian dan pembahasan yang dilakukan secara keseluruhan pada bab sebelumnya, dapat disimpulkan bahwa tidak ada perbedaan yang signifikan antara kelompok yang menggunakan buku pengayaan membaca sastra legenda bermuatan multikultural dengan kelompok yang tidak menggunakan buku pengayaan membaca sastra legenda bemuatan multikultural yang ditunjukkan pada hasil uji-t posttest kelompok eksperimen dan kelompok kontrol. Serta pembelajaran membaca sastra legenda kelompok kontrol dan kelompok eksperimen telah terbukti efektif. Akan tetapi, tingkat keefektifan pembelajaran kedua kelompok tersebut berbeda. Hal ini dapat dibuktikan dengan nilai gain score atau perbedaan kenaikan skor ratarata masing-masing kelompok. Gain score kelompok kontrol adalah 2.09, sedangkan gain score kelompok eksperimen sebesar 3.03, selisih gain score kedua kelompok sebesar 0.94 . Selisih gain score kedua kelompok kurang dari 1,00 sedangkan skor maksimal yang bisa didapat yaitu 40,00. Sehingga nilai gain score tersebut tidak dapat membuktikan bahwa strategi Mastery Learning lebih efektif digunakan dibanding strategi konvensional. Hasil penelitian menunjukkan bahwa pembelajaran membaca sastra legenda dengan buku 
pengayaan membaca sastra legenda bemuatan multikultural tidak tidak lebih efektif untuk meningkatkan nilai rerata siswa dibandingkan dengan yang tidak 69 menggunakan buku pengayaan membaca sastra legenda bemuatan multikultural. Hasil tersebut dapat berimplikasi secara teoritis dan praktis. Secara teoretis, penelitian ini memberikan bukti bahwa penerapan buku pengayaan membaca sastra legenda bemuatan multikultural pada lokasi yang berbeda dapat menunjukan hasil yang berbeda pula. Secara praktis, buku pengayaan membaca sastra legenda bemuatan multikultural dapat digunakan guru untuk pembelajaran membaca sastra legenda.

\section{SARAN}

Berdasarkan simpulan dan implikasi di atas, dapat ditarik beberapa saran sebagai berikut:

1.Pembelajaran membaca sastra legenda yang dilaksanakan hendaknya menggunakan cara yang lebih bervariasi agar siswa merasa tertarik.

2. buku pengayaan membaca sastra legenda bemuatan multikultural dapat digunakan sebagai salah satu strategi dalam pembelajaran membaca sastra legenda.

\section{REFERENCES}

[1] Tarigan, Henry Guntur, 2008. Membaca: Sebagai Suatu Keterampilan Berbahasa, bandung; Angkasa Bandung.

[2] Mulyani, Mimi., 2011, Kearifan Budaya Lokal Yang Berorientasi Pendidikan Karakter Sebagai Sumber Inspirasi Menulis pada Siswa SMP, Proceding Internasional: Pengembangan Peran Bahasa dan Sastra Indonesia untuk Mewujudkan Pendidikan Yang berkarakter,
Surakarta; PIBSI XXXV [online], available : $\quad$ https://onlinejournal.unja.ac.id/index.php/pena/ article/view/1427

[3] Suwardi, 2011, Pengembangan Bahan Aja Membaca Intensif di SMP Dengan prinsip Kontekstual, Tesis, Semarang; UNNES.

[4] Parrish, Patrick., and Jennifer A, Linder Van Berschot., 2010. Cultural Dimensions of Learning. Addressing the Challenges of Multicultural Intruction, Jurnal Science Teacher Education, Vol 11 No 2 May 2019, [online] available:

https://www.researchgate.net/publ ication/44098993_Cultural_Dime nsions_of_Learning_Addressing_t he_Challenges_of_Multicultural_I nstruction

[5] Sitepu, Bintang Petrus, 2012, Penulisan Buku Teks Pelajaran. Bandung: Remaja Rosdakarya.

[6] Soedarso, 2004, Speed Reading: Sistem Membaca Cepat dan efektif, Jakarta; Gramedia Pustaka Utama.

[7] Rahim, Farida., 2007, Pengajaran Membaca di Sekolah Dasar, Jakarta; Bumi Aksara.

[8] Abiding, Yunus., 2012, Pembelajaran Bahasa Berbasis Pendidikan Karakter, Bandung; Refika Aditama.

[9] Nurhadi, 2008, Membaca Cepat dan Efektif. Bandung; Sinar Baru Algesindo.

[10] Haryadi, 2014, Pengembangan Buku Ajar Membaca yang Bermuatan Kreativitas Berpikir dan Nilai-Nilai Pendidikan Karakter, Disertasi, Semarang; Program Pascasarjana Unnes.

[11] Subyantoro, 2009, Pelangi Pembelajaran Bahasa, Tinjauan Semata Burung Psikolinguistik, Semarang; UNNES. 
[12] Rahmat, Pupu Saeful., 2008, Wacana Pendidikan Multikultur di Indonesia : Sebuah Kajian terhadap Masalah-Masalah Sosial yang Terjadi Dewasa ini. Available http://akhmadsudrajat.wordpress.c om

[13] Cucu, 2003, Kontribusi Pengajaran Geografi terhadap Pembentukan Sikap Multikultural Siswa (Studi Deskriptip Analitik di Lingkungan SLTP Negeri di Kota Tangerang), Tesis, Bandung:Program Pascasarjana UPI.

[14] Stavenhagen, Rudolfo., 1996, Education for a Multikultural World, in Jasque Delors et al. Learning: The Treasure Within, Paris, UNESCO.

[15] Mahfud, Choirul., 2009, Pendidikan Multikultural, Cetakan III, Yogyakarta: Pustaka Pelajar.

[16] Yaqin, M.Ainul., 2005, Pendidikan Multikultural : CrossCultural Understanding untuk Demokrasi dan Keadilan, Yogyakarta : Pilar Media.

[17] Mendatu, Achmanto., 2007, Strategi Meningkatkan Kompetensi Guru dalam Melaksanakan Pendidikan Multikultural, available : http://smartpsikologi.blogspot.co $\underline{\mathrm{m}}$

[18] Sugiyono, 2008, Metode Penelitian Kuantitatif Kualitatif dan $R \& D$, Bandung : Alfabeta. 